\title{
ANALISIS KONSUMSI ENERGI DAN PROGRAM KONSERVASI ENERGI (STUDI KASUS: GEDUNG PERKANTORAN DAN KOMPLEKS PERUMAHAN TI)
}

\author{
Siska Ayu Kartika \\ Program Studi Teknik Mesin, Fakultas Teknologi Industri, Universitas Balikpapan \\ Jl. Pupuk Raya, Balikpapan, Kalimantan Timur \\ E-mail : siska.ayukartika@uniba-bpn.ac.id
}

\begin{abstract}
ABSTRAK
Pertumbuhan jumlah penduduk dan kegiatan industri yang pesat saat ini mengakibatkan kebutuhan dan pemakaian listrik yang terus meningkat setiap tahunnya. Perusahaan TI sebagai salah satu perusahaan di Balikpapan, terpacu untuk turut serta melakukan upaya hemat energi, dimana hal ini sejalan dengan Peraturan Pemerintah No. 70/2009 tentang Konservasi Energi. Untuk dapat melakukan hal tersebut, maka perlu dilakukan langkah awal dengan melakukan audit energi, yaitu suatu metode untuk menghitung tingkat konsumsi energi suatu gedung/bangunan. Tujuan dari penulisan ini adalah untuk melakukan analisis konsumsi energi dan program konservasi energi di gedung perkantoran dan kompleks perumahan TI.

Metode penelitian yang dilakukan diawali dengan observasi lapangan, mengumpulkan data historis pemakaian listrik dari tahun 2007, melakukan audit energi, untuk menghitung Intensitas Konsumsi Energi (IKE). Nilai IKE tahun 2007 sebesar $28.09 \mathrm{Kwh} / \mathrm{m}^{2} /$ bulan, dan ini termasuk dalam kategori sangat boros, sehingga perlu dilakukan program konservasi energi. Setelah dilakukan program konservasi energi, didapatkan nilai IKE pada 2017 adalah 13,80 Kwh/m²/bulan, termasuk dalam kategori cukup efisien. Pemakaian listrik secara keseluruhan dari tahun 2007 - 2017, sudah menunjukkan adanya penurunan pemakaian listrik yang signifikan, yaitu sebesar 12\%, dimana rata-rata pemakaian listrik tahun 2010 - 2017 menjadi 1.216 Mwh/bulan dibandingkan dengan rata-rata tahun 2007 - 2009 sebesar 1.375 Mwh/bulan, sebelum dilakukan program hemat energi.
\end{abstract}

Kata kunci : Audit Energi, Intensitas Konsumsi Energi, Konservasi Energi

\section{PENDAHULUAN}

Secara umum konsumsi energi mengalami kenaikan, sejalan dengan pertumbuhan ekonomi dan pola hidup. Laju pertumbuhan konsumsi energi, termasuk biomassa mencapai $4,1 \%$ per tahun, lebih tinggi dari laju pertumbuhan konsumsi dunia yaitu 2,6\%. Pertumbuhan konsumsi energi terjadi di seluruh sektor, yaitu meliputi sektor industri, rumah tangga, komersial, transportasi, dan sektor lainnya. Terdapat tiga sektor utama sebagai konsumsi energi terbesar, yaitu sektor industri yang mencapai $33 \%$, disusul sektor rumah tangga sebesar $27 \%$ dan sektor transportasi sebesar 27\% (ESDM and ESP3, 2016).

Sementara itu, dalam data yang lain menunjukkan pertumbuhan ekonomi di Indonesia, terutama didorong dari sektor industri dan transportasi. Di tahun 2000 sektor industri mengkonsumsi energi sebesar 193 juta Setara Barel Minyak (SBM), dan kemudian meningkat menjadi lebih dari $80 \%$ di tahun 2013. Sedangkan konsumsi energi di sektor transportasi meningkat lebih dari 2.5 kali lipat dari tahun 2000 ke 2013. Tingkat peningkatan konsumsi energi berada pada tingkat ratarata 6.3\%/tahun sepanjang tahun 2000 hingga 2013. Namun pertumbuhan konsumsi energi yang pesat ternyata tidak diikuti oleh upaya peningkatan efisiensi energi di berbagai sektor. Peluang penghematan energi baik pada sector industri maupun sektor bangunan dan komersial di Indonesia cukup besar, yaitu rata-rata sebesar 10-30\%. Pemerintah Indonesia pada tahun 2025 memiliki target untuk melakukan penghematan energi di sektor industri sebesar $17 \%$, sedangkan di sektor transportasi sebesar 20\% (Otoritas Jasa Keuangan, 2015).

Semakin tinggi pertumbuhan ekonomi suatu daerah maka semakin meningkat pula penggunaan konsumsi energi pada daerah tersebut. Hal ini dikarenakan setiap aktifitas masyarakatnya membutuhkan energi, sedangkan disisi lain sumber energi semakin menipis, sebagaimana halnya energi yang dipakai setiap hari. Semakin berkurang sumber energi tersebut, maka akan menyebabkan krisis energi diseluruh Indonesia. Kondisi ini terjadi dikarenakan permintaan energi yang semakin meningkat, sedangkan ketersediaan jumlah energi semakin sedikit. Hal ini menyebabkan nilai energi semakin hari semakin tinggi sehingga penggunaan energi yang efektif dan efisien sangat dibutuhkan.

Undang-Undang No. 30 Tahun Tahun 2007 tentang Energi adalah landasan hukum utama pengelolaan energi 
Nasional, dengan salah satu pertimbangan utamanya adalah keterbatasan cadangan sumber daya energi tak terbarukan sehingga diperlukan penganekaragaman sumber daya energi untuk menjamin ketersediaan energi (ESDM and ESP3, 2016).

Konservasi energi adalah upaya sistematis, terencana, dan terpadu guna melestarikan sumber daya energi dalam negeri serta meningkatkan efisiensi pemanfaatannya. Dalam kaitannya konservasi energi untuk mencapai tercapainya ketahanan energi nasional, pemerintah telah menerbitkan berbagai regulasi mulai dari yang tertinggi yaitu Undang-Undang No. 30 Tahun 2007 tentang Energi, Peraturan Pemerintah No. 70 Tahun 2009 tentang Konservasi Energi, Instruksi Presiden dan berbagai peraturan menteri sebagai petunjuk operasionalnya.

Dalam Peraturan Pemerintah No. 70 Tahun 2009 tentang Konservasi Energi diamanatkan bahwa konservasi energi menjadi tanggung jawab pemerintah, pemerintah daerah, pengusaha dan masyarakat. Selain itu konservasi energi nasional meliputi seluruh tahap pengelolaan energi, yaitu kegiatan penyediaan, pengusahaan, dan pemanfaatan energi serta konservasi sumber daya energi (ESDM and ESP3, 2016).

Menurut Peraturan Pemerintah No. 70 Tahun 2009 tentang Konservasi Energi, definisi konservasi energi adalah upaya sistematis, terencana dan terpadu guna melestarikan sumber daya energi dalam negeri serta meningkatkan efisiensi pemanfaatannya. Oleh karenanya, pengusaha dituntut untuk dapat melaksanakan konservasi energi dalam setiap tahap pelaksanaan usaha; dan menggunakan teknologi yang efisien energi; dan/ atau menghasilkan produk dan/atau jasa yang hemat energi (PP, 2009).

Efisiensi merupakan salah satu langkah dalam pelaksanaan konservasi energi. Efisiensi energi adalah istilah umum yang mengacu pada penggunaan energi lebih sedikit untuk menghasilkan jumlah layanan atau output berguna yang sama.

Konservasi dalam pemanfaatan energi menyebutkan pemanfaatan energi oleh pengguna sumber energi dan pengguna energi wajib dilakukan secara hemat dan efisien (ESDM and ESP3, 2016).

Untuk dapat melakukan hal tersebut, maka perlu dilakukan langkah awal dengan melakukan Audit Energi, yaitu teknik yang dipakai untuk menghitung besarnya konsumsi energi pada bangunan gedung dan mengenali cara-cara untuk penghematannya. Audit Energi bertujuan mengetahui "Potret Penggunaan Energi" dan mencari upaya peningkatan efisiensi penggunaan energi (Badan Standardisasi Nasional, 2000). Kemudian hasil dari audit energi tersebut nanti akan dibandingkan dengan standar yang ada dan kemudian dicari solusi penghematan konsumsi energi jika tingkat konsumsi energinya melebihi standar yang ada.

Gedung perkantoran adalah salah satu yang memiliki ketergantungan tinggi terhadap kebutuhan energi listrik terutama untuk memenuhi kebutuhan operasionalnya.
Namun pada kenyataannya proses audit energi masih jarang diterapkan di Indonesia, terutama bagi gedunggedung komersial seperti gedung perkantoran, sekolah, universitas, rumah sakit maupun gedung komersial lainnya.

Mengacu dari beberapa penelitian sebelumnya mengenai pelaksanaan audit energi yang dilakukan, hasil dari audit energi tersebut terbukti dapat memberikan gambaran bagi perusahaan mengenai konsumsi energi per tahunnya, sehingga dapat memberikan rekomendasi Program Hemat Energi (PHE) untuk periode selanjutnya (Untoro, Gusmedi and Purwasih, 2014). Begitu pula tujuan dari audit energi untuk mengetahui profil penggunaan energi, peluang penghematan energi dan besarnya Intensitas Konsumsi Energi serta tingkat efisiensi di gedung perkantoran, mengingat penggunaan energi di beberapa gedung perkantoran belum bisa dikatakan efisien, sehingga diperlukan upaya lebih lanjut untuk dapat lebih meningkatkan efisiensi penggunaan energi (Riyadi dan Tambunan, 2016). Selain itu, dalam penelitian lain disebutkan perlu agar dilakukan penelitian tentang IKE dan PHE diseluruh perkantoran yang pemakaian dan biaya konsumsi listriknya boros (Samhuddin, Kadir, 2017).

Kebutuhan energi yang tinggi menuntut manajemen di gedung perkantoran dan kompleks perumahan TI melakukan efisiensi dalam penggunaannya. TI memiliki beberapa gedung perkantoran yang terpisah, dengan luas total lahan perkantoran sekitar 8 ha dan luas lantai bangunan perkantoran kurang lebih dari $34.242 \mathrm{~m}^{2}$ dan untuk kompleks perumahan kurang lebih $42.385 \mathrm{~m}^{2}$, detail dapat dilihat pada tabel 4. Sumber utama pemakaian listrik berasal dari PLN dan Power Diesel Engine Generator (DEG) GU dan GB.

Manajemen TI memiliki komitmen untuk mematuhi dan menerapkan peraturan yang berlaku, terutama yang terkait dengan masalah konservasi energi. Berdasarkan alasan tersebut diatas, maka penulis perlu untuk melakukan studi analisis terhadap konsumsi energi listrik dan mengidentifikasi program penghematan listrik yang dilakukan di Gedung Perkantoran dan kompleks perumahan TI, dengan melakukan evaluasi terhadap data konsumsi energi mulai dari tahun 2007 hingga 2017, untuk melihat keberhasilan PHE yang dilakukan dan konsistensi dalam penerapannya.

\section{RUANG LINGKUP}

Ruang lingkup penelitian yang dilakukan mencakup beberapa hal sebagai berikut :

1. Pemakaian listrik di gedung perkantoran dan kompleks perumahan TI.

2. Sumber listrik yang digunakan berasal dari PLN dan Power Diesel Engine Generator (DEG) GU dan GB.

3. Data yang dievaluasi mulai dari konsumsi energi tahun 2007 sampai dengan 2010.

4. Program penghematan listrik yang dilakukan TI mulai tahun 2010 hingga 2017. 
5. Evaluasi yang dilakukan tidak memperhitungkan biaya.

\section{BAHAN DAN METODE}

Berikut disajikan bahan/kajian pustaka terkait dengan penelitian ini

\subsection{Manajemen Energi}

Manajemen energi adalah kegiatan di suatu perusahaan yang terorganisir dengan menggunakan prinsip-prinsip manajemen, dengan tujuan agar dapat dilakukan konservasi energi, sehingga biaya energi sebagai salah satu komponen biaya produksi/operasi dapat ditekan serendah-rendahnya.

Konservasi energi sendiri mengandung arti sebagai suatu usaha untuk tetap menggunakan energi secara rasional tapi tetap mempertahankan produktifitas dan terpenuhinya syarat-syarat kelola perusahaan. Penggunaan energi rasional diantaranya dengan penghematan dan efisiensi energi. Jadi harus dibedakan antara penghematan energi dengan konservasi energi.

Penghematan energi bisa saja dilakukan dengan hanya mengurangi penggunaan energinya tapi kenyamanan dan produktitas menjadi turun. Sementara konservasi energi adalah penerapan kaidah-kaidah dalam pengelolaan energi tidak hanya mengurangi pemakaian energinya tapi juga menerapkan pola operasi yang efisien, pemasangan alat tambahan yang meningkatkan performa sistem sehingga pemakaian energinya lebih rendah tapi tidak mengurangi kenyamanan dan produktifitas. Jadi pada intinya konservasi energi merupakan panduan bagaimana menghemat energi dengan benar dan berisi metode-metode dan alat alat yang bisa dipakai untuk penghematan energi tanpa mengurangi produktifitas dan kenyamanan. Sementara efisiensi energi artinya perbandingan antara penggunaan energi dengan hasil produksinya. Yang dimaksud produksinya bisa kenyamanan, gerak dan lain-lain.

Jadi efisiensi energi yang tinggi berarti pemakaian energinya rendah tapi produksi tinggi. Dengan demikian konsep konservasi energi lebih luas dibandingkan dengan efisiensi energi (Hassan, 2014).

Manajemen energi secara umum dapat didefinisikan sebagai manajemen yang berdampak langsung pada organisasi, teknik dan aksi yang ekonomis dalam rangka meminimalisasi konsumsi energi, termasuk energi untuk produksi/kegiatan dan untuk meminimalisasi konsumsi bahan baku dan bahan tambahan lainnya. Dengan demikian manajemen energi merupakan kegiatan yang terstruktur terhadap energi dengan tujuan mengurangi konsumsi energi secara terus menerus dan menjaga peningkatan yang telah dicapai. Manajemen energi dilaksanakan mengikuti pola Deming Circle (PDCA) dimana melalui pembuatan kebijakan, perencanaan aksi, penerapan dan evaluasi yang terus menerus menuju perbaikan. Dengan demikian manajemen energi bukan tujuan tetapi merupakan kegiatan yang memperhatikan energi dalam kegiatan manajemen sehari-hari.
Selain itu hubungan antara manajemen energi dengan operasi harian menjadi suatu kerangka kerja dalam suatu dokumen yang didukung oleh manajemen (ESDM and ESP3, 2016).

\subsection{Audit Energi}

Dalam manajemen energi, untuk mengetahui dan menelusuri aliran penggunaan energi digunakan audit energi sebagai alatnya. Dengan audit energi ini akan diketahui kebocoran-kebocoran penggunaan energi di gedung sehingga dapat ditentukan langkah-langkah yang tepat untuk menekan kebocoran-kebocoran tersebut dan pengelolaan energinya menjadi baik.

Pada bangunan gedung, sistem pengguna energi dapat dikelompokkan pada empat pengguna energi terbesar yaitu : sistem AC, sistem pencahayaan, sistem transportasi gedung dan peralatan kantor lainnya.

Audit energi adalah kegiatan untuk mengetahui pola pemakaian energi dari peralatan pengguna energi yang ada di gedung. Tujuan dilakukan audit energi, adalah untuk menentukan cara yang terbaik untuk mengurangi penggunaan energi per satuan output dan mengurangi biaya operasi gedung.

Suatu kegiatan audit energi adalah merupakan alat untuk mendukung program konservasi energi disuatu fasilitas pengguna energi. Istilah konservasi energi ini harus dibedakan dengan penghematan energi. Konsep yang berlaku dari konservasi energi ini adalah suatu kegiatan untuk mendukung pemakaian energi yang tepat dan efisien pada suatu fasilitas pengguna energi tanpa mengurangi produktifitas atau kenyamanannya. Untuk mencapai ini diperlukan batasan-batasan standar yang harus ditaati.

Uraian diatas akan mengarah kepada pertanyaan kapan suatu fasilitas pengguna energi (gedung atau lainnya) perlu melakukan audit energi.

Sesungguhnya kita tidak secara mudah bisa mengatakan suatu fasilitas pengguna energi itu boros dalam penggunaan energinya, yang paling mungkin kita menduga bahwa suatu fasilitas pengguna energi berindikasi boros energinya. Tapi sebaiknya suatu fasilitas pengguna energi baik gedung ataupun lainnya perlu diaudit penggunaan energinya ada ataupun tidak indikasi penggunaan energi yang boros.

Menurut Pedoman Pelaksanaan Konservasi Energi dan Pengawasannya di Lingkungan Departemen Pendidikan Nasional nilai IKE dari suatu bangunan gedung digolongkan dalam dua kriteria, yaitu untuk bangunan ber-AC dan non-AC. Dalam tabel 1 berikut, adalah standar nilai IKE untuk Gedung ber-AC (Untoro, Gusmedi and Purwasih, 2014). 
Tabel 1. Standar IKE Gedung ber-AC

\begin{tabular}{|c|c|}
\hline$k$ & \\
\hline $\begin{array}{c}\text { Sangat } \\
\quad(50- \\
\mathrm{kWh} / \mathrm{m}^{2}\end{array}$ & $\begin{array}{l}\text { a) Desain gedung sesuai standar } \\
\text { tatacara perencanaan teknis } \\
\text { konservasi energi } \\
\text { b) Pengoperasian peralatan } \\
\text { energi dilakukan dengan prinsip- } \\
\text { prinsip menejemen energi }\end{array}$ \\
\hline $\begin{array}{r}\text { Efis } \\
(95- \\
\text { Wh } / \mathrm{m}^{2}\end{array}$ & $\begin{array}{l}\text { a) Pemeliharaan gedung dan } \\
\text { peralatan energi dilakukan sesuai } \\
\text { prosedur } \\
\text { b) Efisiensi penggunaan energi } \\
\text { masih mungkin ditingkatkan } \\
\text { melalui penerapan sistem } \\
\text { menejemen energi terpadu }\end{array}$ \\
\hline $\begin{array}{r}\text { Cukup } \\
\quad(95- \\
\mathrm{kWh} / \mathrm{m}\end{array}$ & $\begin{array}{l}\text { a) Penggunaan energi cukup } \\
\text { efisien melalui pemeliharaan } \\
\text { bangunan dan peralatan energi } \\
\text { masih memungkinkan } \\
\text { b) Pengoperasian } \\
\text { pemeliharaan gedung belum } \\
\text { mempertimbangkan } \\
\text { konservasi energi }\end{array}$ \\
\hline & $\begin{array}{l}\text { a) Audit energi perlu } \\
\text { dipertimbangkan } \\
\text { menentukan perbaikan efisiensi } \\
\text { yang mungkin dilakukan } \\
\text { b) Desain bangunan maupun } \\
\text { pemeliharaan dan pengoperasian } \\
\text { gedung belum } \\
\text { mempertimbangkan konservasi } \\
\text { energi }\end{array}$ \\
\hline $\begin{array}{r}\text { B } \\
(175 \\
\text { Wh/n }\end{array}$ & $\begin{array}{l}\text { a) Audit energi perlu } \\
\text { dipertimbangkan } \\
\text { menentukan langkah-langkah } \\
\text { perbaikan sehingga pemborosan } \\
\text { energi dapat dihindari } \\
\text { b) Instalasi peralatan dan desain } \\
\text { pengoperasian dan pemeliharaan } \\
\text { tidak mengacu pada } \\
\text { penghematan energi }\end{array}$ \\
\hline $\begin{array}{l}\text { Sangat } \\
(285- \\
\mathrm{kWh} / \mathrm{m}^{2} /\end{array}$ & $\begin{array}{l}\text { a) Agar ditinjau ulang atas } \\
\text { semua instalasi /peralatan energi } \\
\text { serta penerapan menejemen } \\
\text { energi dalam pengelolan } \\
\text { bangunan } \\
\text { b) Audit energi adalah langkah } \\
\text { awal yang perlu dilakukan }\end{array}$ \\
\hline
\end{tabular}

\subsection{Intensitas Konsumsi Energi (IKE) Listrik}

Indikator utama penghematan energi di sebuah gedung umumnya menggunakan Intensitas Konsumsi Energi (IKE). IKE menunjukkan besarnya konsumsi energi (kwh) per meter persegi $\left(\mathrm{m}^{2}\right)$ setiap bulan, seperti terlihat pada rumus (1) dibawah ini. Angka IKE $\left(\mathrm{kwh} / \mathrm{m}^{2} /\right.$ bulan) diperoleh dengan membagi jumlah $\mathrm{kwh}$ penggunaan listrik selama sebulan dengan luas bangunan yang digunakan (USAID Indonesia Clean Energy Development, 2014).

$$
\operatorname{IKE}\left(\frac{\mathrm{kWh}}{\mathrm{m}^{2}}\right)=\frac{\text { Total } k W h}{\text { Luas area }}
$$

Untuk perhitungan IKE yang direkomendasikan melalui Permen ESDM No.13 Tahun 2012 dapat dilihat pada tabel 2 (USAID Indonesia Clean Energy Development, 2014), dimana nilai IKE yang dihasilkan akan menentukan apakah sebuah bangunan tergolong sangat efisien, efisien, cukup efisien dan boros.

Tabel 2. Standar Intensitas Konsumsi Energi (IKE) untuk gedung kantor

\begin{tabular}{|c|c|c|}
\hline Kriteria & $\begin{array}{c}\text { Gedung Kantor } \\
\text { ber-AC } \\
\left(\mathbf{k w h} / \mathbf{m}^{\mathbf{2}}\right)\end{array}$ & $\begin{array}{c}\text { Gedung } \\
\text { Kantor tanpa } \\
\mathbf{A C}\left(\mathbf{k w h} / \mathbf{m}^{\mathbf{2}}\right)\end{array}$ \\
\hline Sangat efisien & $<8,5$ & $<3,4$ \\
\hline Efisien & $8,5-14$ & $3,4-5,6$ \\
\hline Cukup efisien & $14-18,5$ & $5,6-7,4$ \\
\hline Boros & $>18,5$ & $>7,4$ \\
\hline
\end{tabular}

Standar IKE dalam tabel 3 yang digunakan sebagai rujukan tingkat penggunaan energi gedung dapat berbeda-beda, dipengaruhi oleh pendekatan analisis dan sampel gedung yang diambil dalam proses perumusan standar tersebut. Nilai IKE juga bersifat dinamis dan sewaktu-waktu dapat berubah (berdasarkan hasil penelitian terbaru) mengikuti perkembangan teknologi peralatan hemat energi dan mengikuti tingkat kesadaran hemat energi pegawai (pengguna gedung). Perhitungan Intensitas Konsumsi Energi (IKE) mengunakan hasil penelitian ASEAN-USAID standar IKE untuk gedung perkantoran adalah $240 \mathrm{Kwh} / \mathrm{m}^{2}$ pertahun. IKE lebih besar dari IKE standar maka ada potensi penghematan (USAID Indonesia Clean Energy Development, 2014). 
Tabel 3. Berbagai Standar Intensitas Konsumsi Energi (IKE) untuk Gedung Perkantoran

\begin{tabular}{|c|c|c|}
\hline Sumber & $\begin{array}{c}\text { IKE } \\
\left(\mathrm{kwh} / \mathrm{m}^{2} / \text { tahun }\right)\end{array}$ & $\begin{array}{c}\text { Tahun } \\
\text { Pengeluaran } \\
\text { Standar }\end{array}$ \\
\hline ASEAN-USAID & 240 & 1987 \\
\hline $\begin{array}{c}\text { ESDM \& JICA } \\
\text { Electric Power } \\
\text { Development Co., } \\
\text { LTD }\end{array}$ & 198,2 & 2008 \\
\hline $\begin{array}{c}\text { GBCI (Konsul } \\
\text { Bangunan Hijau } \\
\text { Indonesia) }\end{array}$ & 250 & 2010 \\
\hline $\begin{array}{c}\text { Pergub DKI } \\
\text { Jakarta No } 38 \\
\text { tahun } 2012 \\
\text { tentang Bangunan } \\
\text { Gedung Hijau }\end{array}$ & $210-285$ & - \\
\hline
\end{tabular}

\subsection{Tahapan Penelitian}

Di seluruh wilayah perkotaan, terutama di daerah Balikpapan berdiri banyak jenis bangunan gedung, yaitu berupa bangunan gedung perkantoran, komersil, pemerintahan dan sebagainya yang berkontribusi besar dalam konsumsi energi nasional dan berpotensi untuk dilakukan langkah efisiensi energi. Obyek studi ini adalah pemakaian listrik di gedung perkantoran dan kompleks perumahan TI, Balikpapan. Metode penelitian yang digunakan dalam kegiatan ini mengacu pada SNI 03-6196-2000 Prosedur Audit Enrgi pada Bangunan Gedung (Badan Standardisasi Nasional, 2000), dengan detail sebagai berikut :

1. Studi Pustaka, dengan melihat dari literatur dan penelitian sebelumnya yang terkait

2. Interview dan observasi lapangan, untuk mengidentifikasi pemakaian listrik di kegiatan perkantoran dan dikompleks perumahan TI,

3. Studi pendahuluan dengan mengumpulkan data historis pemakaian listrik mulai dari tahun 2007,

4. Melakukan Audit Energi, untuk menghitung Intensitas Konsumsi Energi (IKE) sebelum dan sesudah Program Hemat Energi (PHE), detail bagan alir kegiatan dapat dilihat pada Gambar 1,

5. Mengidentifikasi PHE yang dapat dilakukan.

6. Memantau penerapan PHE yang dilakukan, dengan menghitung konsumsi energi setiap tahunnya dan menghitung nilai IKE.

7. Melakukan evaluasi untuk perbaikan selanjutnya.

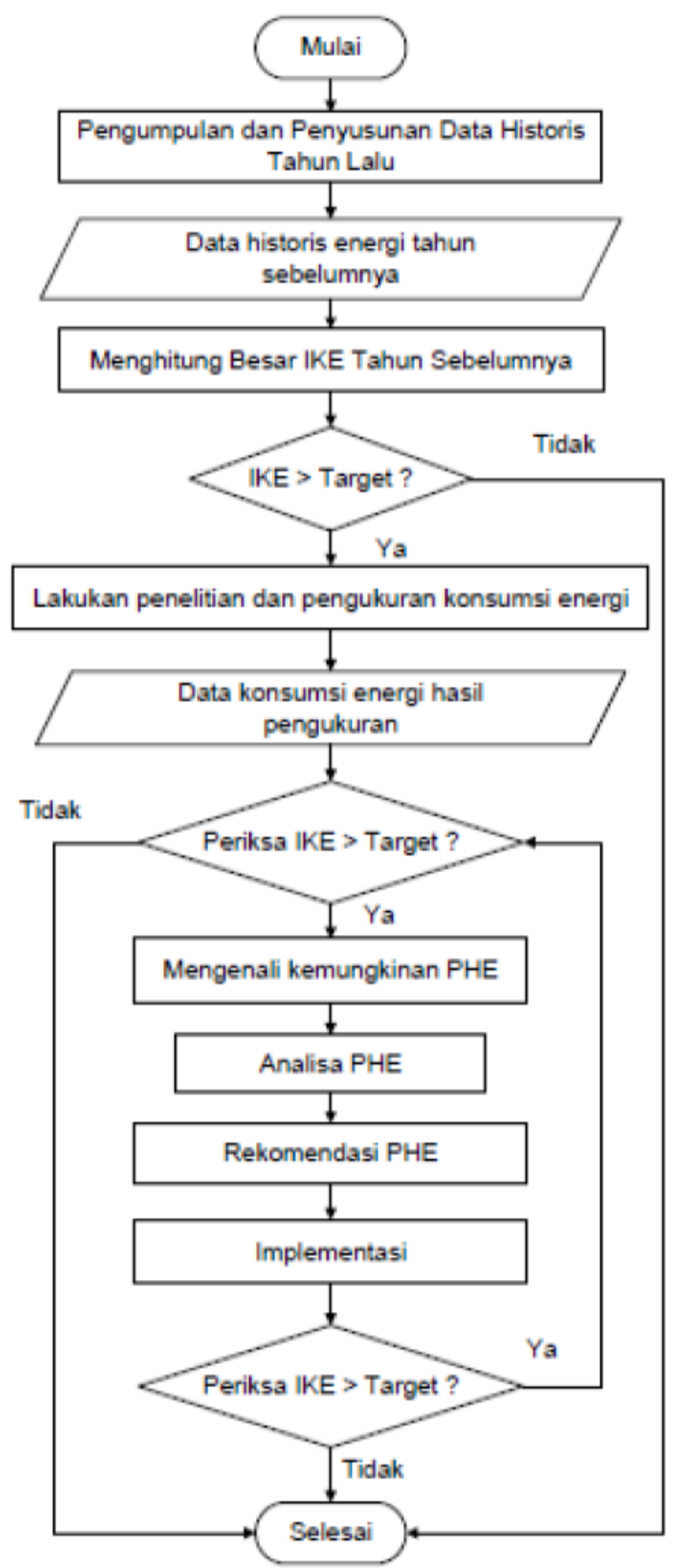

Gambar 1. Bagan Alir Proses Audit Energi

\section{PEMBAHASAN}

Berikut disajikan hasil studi pendahuluan dan hasil penghematan listrik

\subsection{Hasil Studi Pendahuluan}

Dari hasil survei sejumlah pihak (sumber kementrian ESDM) persentasi penggunaan energi peralatan gedung komersial rata-rata adalah seperti terlihat pada gambar 2 di bawah ini (Hassan, 2014). 


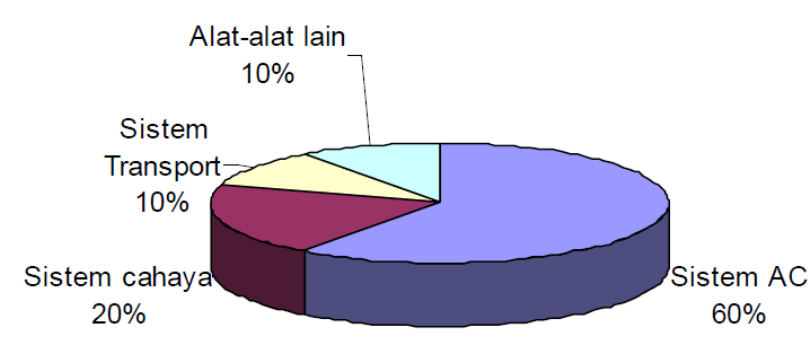

\section{Gambar 2 Persentase Penggunana Energi di Gedung Perkantoran}

Dari gambar terlihat bahwa sistem AC menggunakan energi terbesar sekitar $60 \%$ dari energi gedung dan diikuti oleh pencahayaan sekitar $20 \%$. Apakah implikasinya? Implikasinya adalah bahwa fokus kegiatan konservasi energi ini harus diarahkan terutama ke sistem $\mathrm{AC}$ dan kemudian pencahayaannya karena penghematan dikedua sistem ini akan memberikan hasil yang signifikan dalam program penghematan gedung (Hassan, 2014).

Sedangkan berdasarkan hasil studi pendahuluan, hasil identifikasi pemakaian listrik terbesar dikegiatan perkantoran TI, seperti yang terlihat pada gambar 3 berikut ini.

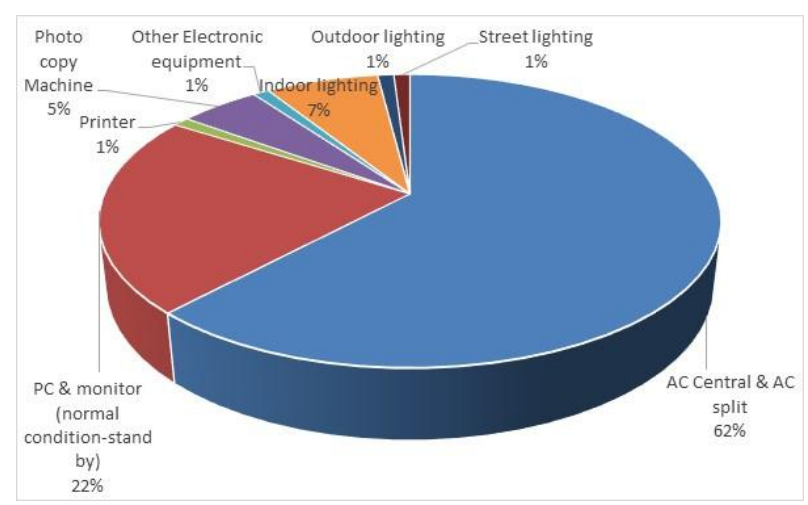

Gambar 3. Hasil Identifikasi Pemakaian Listrik di kegiatan perkantoran TI

Sedangkan untuk kegiatan dikompleks perumahan TI, hasil identifikasi pemakaian listrik dikompleks perumahan TI seperti yang ditunjukkan dalam gambar 4 .

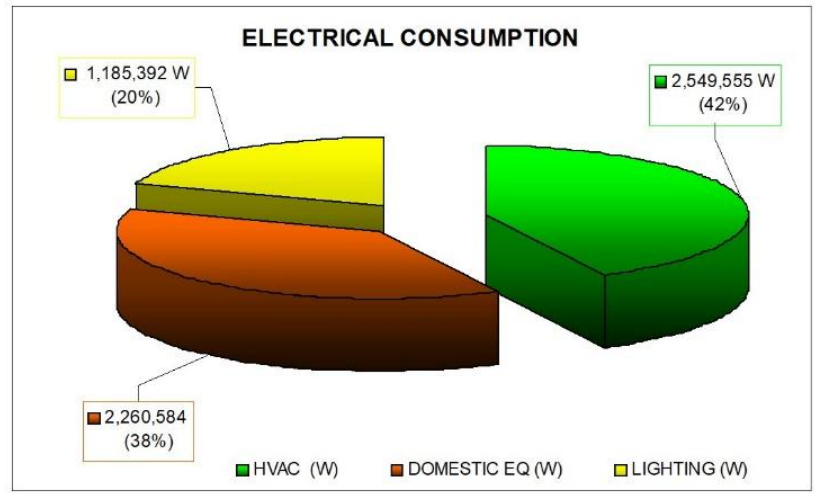

\section{Gambar 4. Hasil Identifikasi Pemakaian Listrik berdasarkan Pemakaian Alat Elektronik di Perumahan}

Untuk hasil identifikasi luas lantai area perkantoran dan dikompleks perumahan dapat dilihat pada tabel 4, sedangkan hasil perhitungan IKE mulai dari tahun 2007 sampai dengan 2017, dapat dilihat pada tabel 4.

Tabel 4. Hasil Identifikasi Luas Lantai Area Perkantoran dan Kompeks Perumahan TI yang menggunakan AC.

\begin{tabular}{|c|c|c|c|}
\hline Tahun & $\begin{array}{l}\text { Area Gedung } \\
\text { Perkantoran } \\
\qquad\left(\mathbf{m}^{2}\right)\end{array}$ & $\begin{array}{c}\text { Kompleks } \\
\text { Perumahan } \\
\left(\mathbf{m}^{2}\right)\end{array}$ & $\begin{array}{c}\text { Gedung } \\
\text { Kantor \& } \\
\text { Area } \\
\text { Perumahan } \\
\left(\mathrm{m}^{2}\right) \\
\end{array}$ \\
\hline 2007 & 15.359 & 32.818 & 48.177 \\
\hline 2008 & 17.601 & 32.845 & 50.446 \\
\hline 2009 & 17.990 & 32.860 & 50.850 \\
\hline 2010 & 20.262 & 32.860 & 53.122 \\
\hline 2011 & 22.354 & 33.273 & 55.627 \\
\hline 2012 & 22.354 & 33.273 & 55.627 \\
\hline 2013 & 22.354 & 33.273 & 55.627 \\
\hline 2014 & 25.134 & 33.273 & 58.407 \\
\hline 2015 & 25.134 & 33.273 & 58.407 \\
\hline 2016 & 28.226 & 36.310 & 64.536 \\
\hline 2017 & 34.242 & 42.385 & 76.627 \\
\hline
\end{tabular}


Tabel 5. Hasil Perhitungan Intensitas Konsumsi Energi (IKE) mulai dari tahun 2007 - 2010

\begin{tabular}{|c|c|c|c|}
\hline \multirow{2}{*}{ Tahun } & \multicolumn{3}{|c|}{ Konsumsi Energi } \\
\cline { 2 - 4 } & $\begin{array}{c}\text { (kwh/m2/ } \\
\text { hari) }\end{array}$ & $\begin{array}{c}\text { (kwh/m2/ } \\
\text { bulan) }\end{array}$ & $\begin{array}{c}\text { (kwh/m2/ } \\
\text { tahun) }\end{array}$ \\
\hline 2007 & 0,94 & 28,09 & 341,72 \\
\hline 2008 & 0,89 & 26,69 & 325,57 \\
\hline 2009 & 0,90 & 26,85 & 326,68 \\
\hline 2010 & 0,82 & 24,73 & 300,93 \\
\hline 2011 & 0,78 & 23,33 & 283,89 \\
\hline 2012 & 0,75 & 22,46 & 273,29 \\
\hline 2013 & 0,72 & 21,58 & 262,52 \\
\hline 2014 & 0,69 & 20,63 & 251,03 \\
\hline 2015 & 0,68 & 20,43 & 248,56 \\
\hline 2016 & 0,55 & 16,52 & 201,56 \\
\hline 2017 & 0,46 & 13,80 & 167,90 \\
\hline
\end{tabular}

Dari tabel 5 diatas, terlihat bahwa nilai IKE tahun 2007 adalah sebesar $341,72 \mathrm{kwh} / \mathrm{m}^{2} /$ tahun atau 28.09 $\mathrm{kwh} / \mathrm{m}^{2} /$ bulan, sehingga jika dibandingkan dengan kriteria IKE seperti yang terlihat pada tabel 1, 2 dan 3, pemakaian listrik di gedung perkantoran dan kompleks perumahan TI termasuk dalam kategori sangat boros, dan juga melebihi dari standar IKE untuk gedung perkantoran yaitu $240 \mathrm{kwh} / \mathrm{m}^{2}$ pertahun.

\subsection{Program Hemat Energi}

Berdasarkan hasil studi pendahuluan tersebut, maka perlu dilakukan beberapa program untuk dapat konservasi energi diantaranya sebagai berikut :

\section{Komitmen Pimpinan Puncak}

Adanya komitmen pimpinan puncak untuk mendukung secara penuh gerakan Program Hemat Energi. Pimpinan Puncak TI pada tanggal 12 Maret 2009 telah menandatangani komitmen untuk mendukung kebijakan program pemerintah di Bidang Konservasi Energi, melalui upaya:

1) Menjadikan kantor TI sebagai kantor yang bersih, hemat energi dan pemakaian air bersih;

2) Mengembangkan budaya TI ke arah budaya bersih, hemat energi dan pemakaian air bersih;

2. Pembentukan Tim Komite Konservasi Energi

Pembentukan Komite Konservasi Energi sejalan dengan komitemen pimpinan puncak untuk menyelamatkan bumi demi masa depan generasi penerus, serta upaya untuk melakukan penghematan penggunaan sumber daya alam yang tidak dapat diperbaharui. TI berinisiatif untuk membentuk Komite Konservasi Energi yang bertugas untuk melakukan kegiatan penghematan. Tugas komite tersebut adalah untuk :
1) Melakukan koordinasi kegiatan-kegiatan konservasi energi;

2) Memantau pelaksanaan program konservasi energi di lingkungan TI;

3) Melakukan kajian dan evaluasi program konservasi energi yang telah dilakukan.

Struktur Komite Konservasi Energi dapat dilihat di gambar 5 .

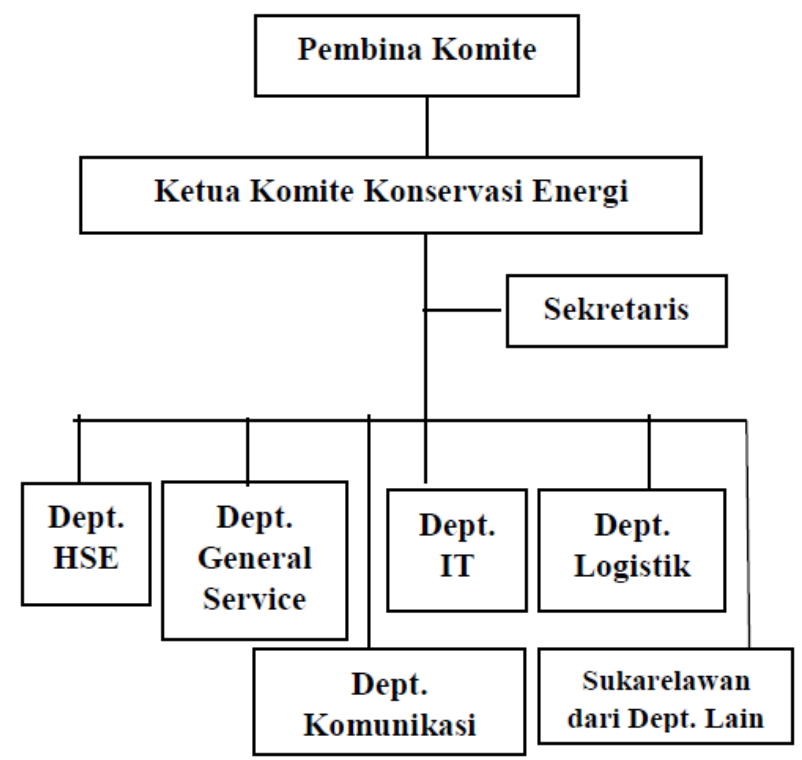

Gambar 5. Struktur Komite Konservasi Energi

3. Sosialisasi

Sosialisasi penghematan pemakaian listrik merupakan bagian dari program yang telah dilaksanakan TI kepada seluruh pegawai, termasuk pegawai outsoursing (satpam, cleaning service, office boy). Kegiatan ini sebagai bentuk peningkatan kesadaran karyawan dengan menjelaskan mengenai manajemen pengelolaan dan penghematan pemakaian listrik di gedung perkantoran dan kompleks perumahan TI. Disamping sosialisasi, untuk meningkatkan kesadaran terhadap penghematan pemakaian listrik juga dilakukan kampanye melalui pemasangan stiker, poster dan banner serta spanduk di seluruh kantor TI.

4. Rekomendasi Kegiatan Penghematan Energi

Melakukan kegiatan beberapa program dalam rangka penghematan penggunaan energi listrik, yaitu :

1) Otomatisasi OFF untuk AC central mulai pukul 21.00 hingga 06.00 di beberapa gedung perkantoran;

2) Menon-aktifkan AC pada saat akhir minggu atau libur, dan untuk di beberapa gedung kantor dilengkapi dengan switch ON/OFF manual dengan timer untuk 2 jam ke depan (yang berfungsi untuk menghidupkan kembali AC secara manual jika karyawan akan bekerja lembur pada hari libur); 
3) Mengganti lampu lama (screw bulb) yang rusak/putus dengan lampu yang hemat energi di area perkantoran dan kompleks perumahan TI;

4) Memasang timer otomatis untuk lampu luar gedung kantor dan di area kompleks perumahan TI (mulai pukul 18.00 - 06.00), sedangkan timer untuk yang di lapangan tenis, basket dan rugby mulai pukul $18.00-21.00$;

5) Memasang duplex printing system sebagai default pada semua mesin fotokopi dan printer, agar dapat mencetak kertas dalam 2 sisi (bolak-balik);

6) Memeriksa ulang penutup pintu secara otomatis dan memperbaiki celah/renggang antar pintu di masing-masing gedung perkantoran, untuk memastikan udara di dalam ruangan tetap selalu dingin (jika menggunakan AC);

7) Menunjuk sukarelawan dari masing-masing gedung, sebagai perwakilan komite hemat energi dalam melakukan sosialisasi dan memantau program hemat energi di masing-masing Gedung;

8) Memasang 100 unit pemanas air dari tenaga surya (solar water heater) di kompleks perumahan TI;

9) Memasang kassa nyamuk di kompleks perumahan (berdasarkan permintaan dari penghuni untuk sirkulasi udara secara alami daripada menyalakan $\mathrm{AC})$;

Setelah dilakukan program penghematan energi tersebut, kemudian dihitung kembali nilai IKE, dan dari hasil perhitungan seperti yang terlihat pada gambar 6, terlihat bahwa nilai IKE tahun 2017 adalah 167,90 $\mathrm{Kwh} / \mathrm{m}^{2} /$ tahun atau $13,80 \mathrm{Kwh} / \mathrm{m}^{2} /$ bulan, sehingga jika dibandingkan dengan kriteria IKE seperti yang terlihat pada tabel 2 dan 3, pemakaian listrik di gedung perkantoran dan kompleks perumahan TI termasuk dalam kategori cukup efisien, dan sudah dibawah dari standar IKE untuk gedung perkantoran adalah 240 $\mathrm{Kwh} / \mathrm{m}^{2} /$ pertahun, meskipun untuk kategori pemakaian per tahunnya sesuai standar di tabel 1 , masih relatif agak boros.

Adapun pemakaian listrik secara keseluruhan dari tahun 2007 - 2017, dapat dilihat pada gambar 7, sudah menunjukkan adanya penurunan pemakaian listrik yang signifikan. Jika dihitung rata-rata pemakain listrik perbulannya menunjukkan adanya penurunan pemakaian listrik sebesar 12\% (gambar 8), dimana pemakaian listrik rata-rata mulai dari tahun 2010 - 2017 sebesar 1.216 Mwh/bulan dibandingkan dengan pemakaian pemakaian listrik di tahun 2007 - 2009 rata-rata sebesar 1.375 Mwh/bulan, sebelum dilakukan program penghematan pemakaian listrik.

Penurunan yang sangat signifikan ditahun 2016 dan 2017 adalah karena diarea gedung perkantoran TI juga telah menggunakan Solar Panel untuk penyediaan listriknya.

Selain itu, sejalan dengan program penghematan energi ini, juga terlihat dari penurunan pemakaian bahan bakar (tabel 6) dan perbandingan penggunaan bahan bakar dengan energi yang dihasilkan pada Power DEG GU dan GB, seperti yang terlihat pada tabel 7, menjadi $0,28 \mathrm{~L} / \mathrm{kwh}$.

Tabel 6. Rata-rata Pemakaian Bahan Bakar per bulan untuk Power (Diesel Engine Generator/DEG)

\begin{tabular}{|c|c|c|}
\hline \multirow{2}{*}{ Tahun } & \multicolumn{2}{|c|}{$\begin{array}{c}\text { Pemakaian Bahan Bakar untuk Power } \\
\text { DEG }\end{array}$} \\
\cline { 2 - 3 } & $\mathbf{m}^{\mathbf{3}} / \mathbf{\text { bulan }}$ & $\mathbf{m}^{\mathbf{3}}$ /hari \\
\hline 2007 & 297 & 9,78 \\
\hline 2008 & 284 & 9,31 \\
\hline 2009 & 272 & 8,95 \\
\hline 2010 & 245 & 8,04 \\
\hline 2011 & 234 & 7,68 \\
\hline 2012 & 244 & 7,98 \\
\hline 2013 & 300 & 9,87 \\
\hline 2014 & 274 & 9,01 \\
\hline 2015 & 246 & 8,08 \\
\hline 2016 & 123 & 5,75 \\
\hline 2017 & 40 & 1,37 \\
\hline
\end{tabular}

Tabel 7. Perbandingan Pemakaian Bahan Bakar dengan Energi yang dihasilkan dari Power DEG GU dan Power DEG GB (L/Kwh)

\begin{tabular}{|c|c|c|}
\hline Tahun & $\begin{array}{c}\text { Power DEG GU } \\
(\mathbf{L} / \mathbf{k w h})\end{array}$ & $\begin{array}{c}\text { Power DEG GB } \\
(\mathbf{L} / \mathbf{k w h})\end{array}$ \\
\hline 2007 & 0,31 & 0,31 \\
\hline 2008 & 0,31 & 0,31 \\
\hline 2009 & 0,30 & 0,29 \\
\hline 2010 & 0,30 & 0,29 \\
\hline 2011 & 0,31 & 0,32 \\
\hline 2012 & 0,33 & 0,31 \\
\hline 2013 & 0,35 & 0,31 \\
\hline 2014 & 0,38 & 0,29 \\
\hline 2015 & 0,38 & 0,30 \\
\hline 2016 & 0,28 & 0,28 \\
\hline 2017 & 0,28 & 0,28 \\
\hline
\end{tabular}




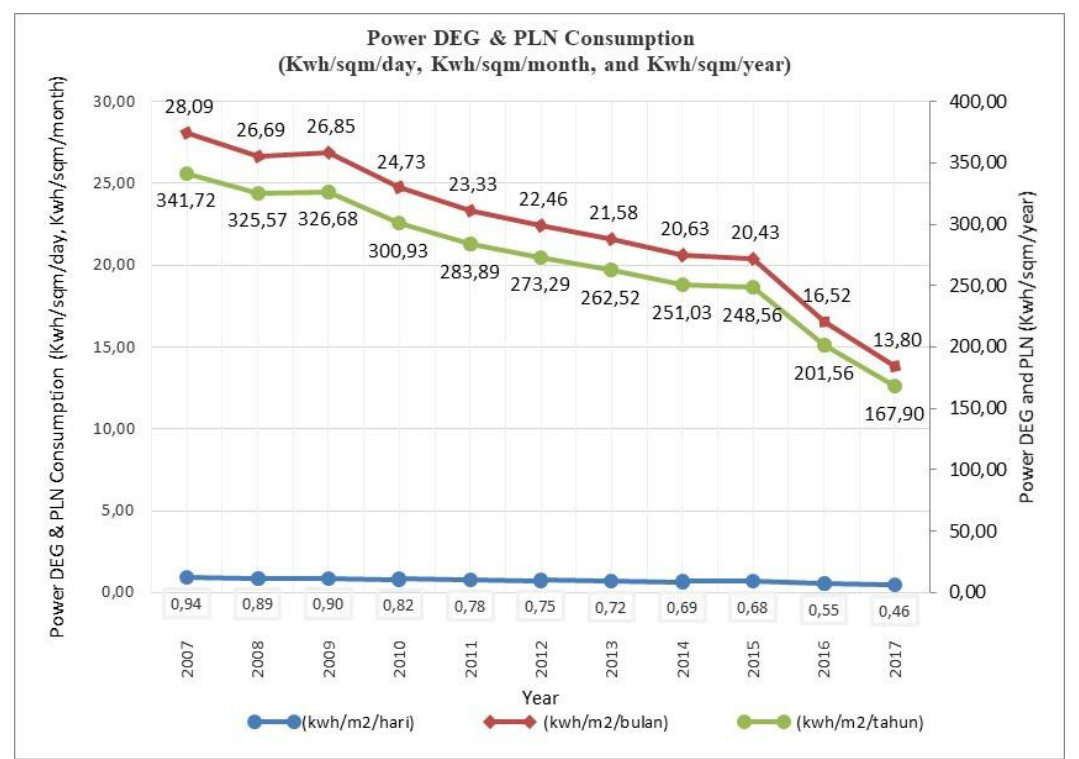

Gambar 6. Hasil Perhitungan Intensitas Konsumsi Energi (IKE) mulai dari tahun 2007 - 2017

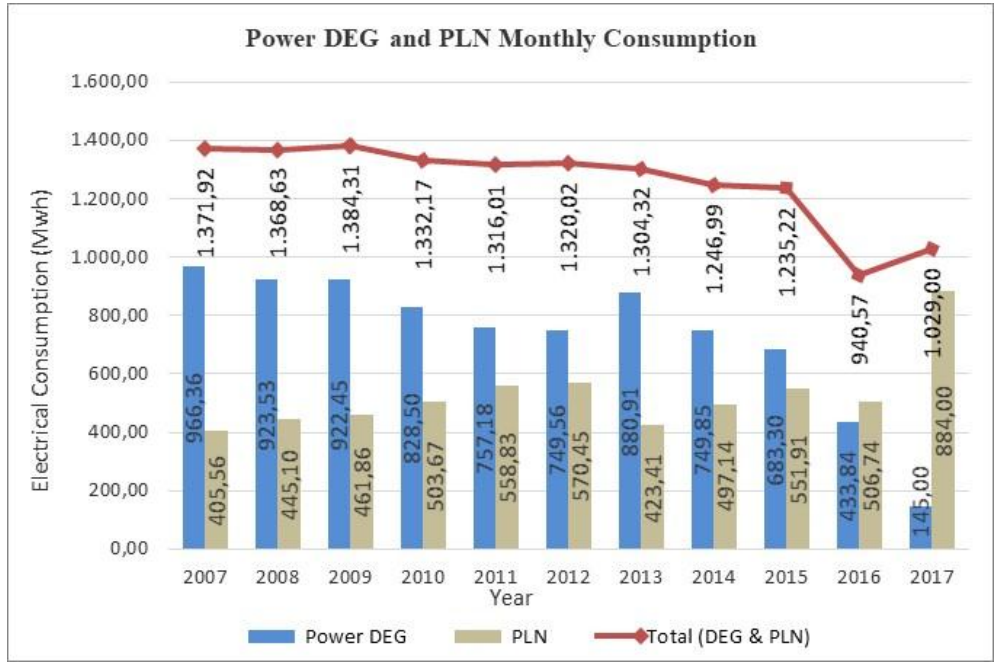

Gambar 7. Pemakaian Pemakaian Listrik dari PLN dan Power DEG mulai tahun 2007 - 2017

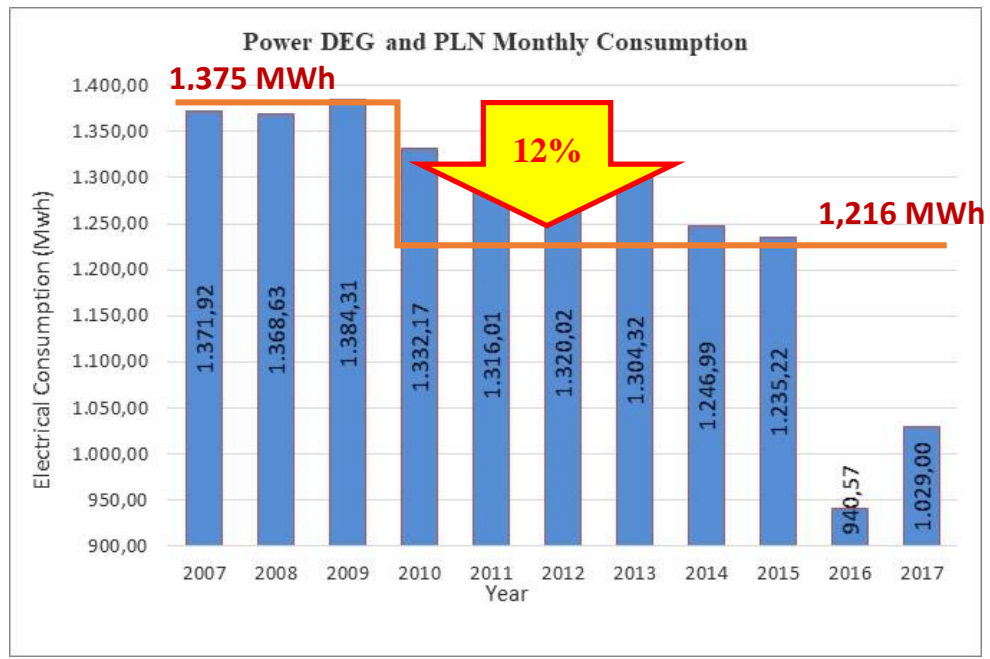

Gambar 8. Prosentasi penurunan pemakaian listrik dari tahun 2007 - 2017 


\section{KESIMPULAN}

Beberapa Program Hemat Energi (PHE) telah dilaksanakan mulai tahun 2010 hingga 2017 diarea Gedung Perkantoran dan Kompleks Perumahan TI. Diantaranya peningkatan kesadaran mengenai pentingnya melakukan penghematan penggunaan listrik kepada seluruh karyawan TI, otomatisasi OFF untuk AC central mulai pukul 21.00 hingga 06.00 , menon-aktifkan AC pada saat akhir minggu atau libur, melengkapi dengan switch ON/OFF manual dengan timer untuk 2 jam ke depan (yang berfungsi untuk menghidupkan kembali AC secara manual jika karyawan akan bekerja lembur pada hari libur), mengganti lampu lama (screw bulb) yang rusak/putus dengan lampu yang hemat energi, memasang timer otomatis untuk lampu luar, memasang duplex printing system sebagai default pada semua mesin fotokopi dan printer, memeriksa ulang penutup pintu secara otomatis dan memperbaiki celah/renggang antar pintu di masing-masing gedung perkantoran, dan memasang 100 unit pemanas air dari tenaga surya (solar water heater) di kompleks perumahan TI;

Setelah dilakukan PHE tersebut maka dapat terlihat hasil perhitungan IKE (Intensitas Konsumsi Energi) pada 2017 adalah 167,90 $\mathrm{kwh} / \mathrm{m}^{2} /$ tahun atau 13,80 $\mathrm{kwh} / \mathrm{m}^{2} / \mathrm{bulan}$, termasuk dalam kategori cukup efisien, dan sudah dibawah dari standar IKE untuk gedung perkantoran $\left(240 \mathrm{kwh} / \mathrm{m}^{2}\right.$ pertahun $)$.

Sedangkan Selain untuk pemakaian listrik secara keseluruhan dari tahun 2007 - 2017, sudah menunjukkan adanya penurunan pemakaian listrik yang signifikan, yaitu sebesar $12 \%$, dimana rata-rata pemakaian listrik mulai dari tahun 2010 - 2017 menjadi 1.216 Mwh/bulan dibandingkan dengan rata-rata pemakaian pemakaian listrik di tahun 2007 - 2009 sebesar 1.375 Mwh/bulan, sebelum dilakukan program penghematan pemakaian listrik.

\section{SARAN}

Untuk mendapatkan efisiensi penghematan pemakaian listrik yang lebih baik, maka perlu untuk memperhatikan hal-hal yang berkaitan dengan desain gedung, pengoperasian dan pemeliharaan gedung yang memperhatikan masalah konservasi energi. Selain itu, perlu dilakukan studi lebih lanjut, mengenai peluang rekomendasi program konservasi energi yang lain, terutama yang mebutuhkan biaya yang lebih tinggi, misalnya : retrofit timer control \& auto timed swicth off pada penerangan esensial, pengaturan beban kelistrikan dengan mengeliminasi beban listrik tidak seimbang full rewiring, pembenahan control panel dan sistem metering disemua bagian, dll.

\section{DAFTAR PUSTAKA}

Anonim. 2017. Laporan Pemakaian Pemakaian Listrik Kantor dan Kompleks Perumahan TI, Balikpapan : Dept. General Service, TI.
Badan Standardisasi Nasional. 2000. Prosedur Audit Energi Pada Bangunan Gedung, Sni 03-61962000.

ESDM, K. and ESP3. 2016. Modul Manajer Energi di Industri dan Gedung.

Hassan, S. 2014. Pelaksanaan Efisiensi Energi Di Bangunan Gedung. www.nulisbuku.com.

Otoritas Jasa Keuangan. 2015. Buku Pedoman Pembiayaan Efisiensi Energi di Industri untuk Lembaga Jasa Keuangan, Otoritas Jasa Keuangan.

PP. 2009. Peraturan Pemerintah No 70 tahun 2009 tentang Konservasi Energi. Jakarta.

Riyadi, S., Tambunan, J.M., Analisis Peningkatan Efisiensi Penggunaan Energi Listrik Pada Sistem Pencahayaan Dan Air Conditioning Di Gedung Graha Mustika Ratu, Proseeding Seminar Nasional Teknologi dan Energi, Program Studi Teknik Elektro, Sekolah Tinggi Teknologi Indonesia, Jakarta.

Samhuddin, Kadir, M. S. 2017. Analisis Konsumsi Energi pada Kantor Pelayanan Kekayaan Negara dan Lelang (KPKNL) Kendari, ENTHALPYJurnal Ilmiah Mahasiswa Teknik Mesin, 2(3). doi: e-ISSN-2502-8944.

Untoro, J., Gusmedi, H. and Purwasih, N. 2014. Audit Energi dan Analisis Penghematan Konsumsi Energi pada Sistem Peralatan Listrik di Gedung Pelayanan Unila, Jurnal Rekayasa dan Teknologi Elektro, 8(2), pp. 93-104.

USAID Indonesia Clean Energy Development. 2014. Panduan Penghematan Energi di Gedung Pemerintah. Available at: www.iced.or.id.

\section{UCAPAN TERIMA KASIH}

Ucapan terima kasih kepada Pimpinan dan pihak-pihak terkait yang ada di Perusahaan TI yang telah memberikan kesempatan untuk melakukan pengamatan, pengambilan data dan evaluasi berdasarkan aturan yang berlaku 
